\title{
THE ROLE OF FINANCIAL CONTROLLING IN THE MANAGEMENT SYSTEM OF TOURISM AND RECREATIONAL COMPANY
}

\section{Maia Seliverstova}

Sochi State University, Sochi, Russia

\section{ANNOTATION}

In the modern world tourism and recreation are highly profitable activities, which also have a significant impact on the economy of the country, contributing to the inflow of foreign currency, creating new jobs, improving infrastructure and so on. In the conditions of economic instability and high level of market competition, success of financial-economic activity of tourism enterprises is determined by the efficiency of decision-making that directly depends on the total access to information about the financial state and existing risks. One of the most efficient tools to allow the company to ensure an organized system of information is financial controlling. The article reveals the role, importance and place of financial controlling in the management system of tourism enterprises, its main tasks and functions.

Keywords: financial controlling, control system, tourism and recreational company.

\section{INTRODUCTION}

Relevance of the research. In the tourism business, natural resources are intensively used and consumed, and tourism has major impacts on environment, ecosystems, economy, societies and culture. If it is managed well, tourism can contribute significantly to regional development; if not, it can have devastating effects on nature and society.

Tourism is in comparison with other industries dependent on national, regional and local resources (e.g. destinations, attractions, etc.) of a country. It is an industry which is bound to territory. Other industries generally depend on natural resources and / or services. Furthermore, tourism depends on traditions, culture, etc. These features are incorporated into tourism businesses becoming part of the tourism industry. This in turn creates a cross-sectoral, dynamic approach to tourism with a corresponding management schema. In the times of globalization and intense competition, the role of analytics and planning increases, both at the macro and micro levels.

According to R. Bekeris (2012), the economic development is a dynamic process affecting SMEs on both macro and micro levels, both nationally and internationally.

As we take stock of the progress that has been made over the past five years, we see that companies are placing big bets on data and analytics. But adapting to an era of more data-driven decision making has not always proven to be a simple proposition for people or organizations. Many are struggling to develop talent, business processes, and organizational muscle to capture real value from analytics. This is becoming a matter of urgency, since analytics' prowess is increasingly becoming the basis of industry competition, and the leaders are staking-out large advantages. Meanwhile, the technology itself is taking major leaps forward - and the next generation of technologies promises to be even more disruptive. Machine learning and deep learning capabilities have an enormous variety of applications that stretch deep into sectors of the economy that have largely stayed on the sidelines thus far (Bughin et al., 2016). 
All economic entities in a market economy aim to achieve the efficiency of economic activity, and to obtain the maximum possible profit. Controlling is the most important function of enterprise management, as well as one of the most effective methods of operation.

The aim of the research was to identify the role of financial controlling in the management system of tourism and recreational company.

Research methods used for this research paper were analysis, synthesis, comparison, classification and grouping.

The object was the role of financial controlling in the management system.

It is believed that controlling as economic term was discovered in Europe in the 15th century, after that it gained wide development in the United States. In Russia, the concept of controlling became popular in the 1990s.

\section{RESEARCH METHODS}

There are various interpretations of the "controlling" concept in the scientific literature. Number of Russian and foreign scientists have devoted their work to studying the essence of this process: D. Hahn (1997), N. G. Danilochkina (1998), D. Kazansky (1999), R. Mann (2004), etc.

Russian authors mostly consider controlling in the narrow sense. N. G. Danilochkina (1998) determines controlling as "the direction of economic work of the enterprise, related to the implementation of financial and economic commenting functions in management for the adoption of operational and strategic management decisions" (p. 6). In their study, E. A. Utkin and E. V. Myrynjuk, describes controlling as a set of accounting, planning and marketing (Utkin, Myrynjuk, 1999).

Foreign definitions of this term differ in a deeper content. The authors suggest not only economic notions about the importance of controlling for an enterprise, but for the philosophical ones. A. Deyhle (2001) (the founder of the controlling academy) understands this term as "the process of mastering the economic situation in the enterprise" (p. 11) R. Mann and E. Meyer (2004) define controlling as "managing the future to ensure the long-term operation of the enterprise and its structural units" (p. 13). The definition of Professor D. Hahn (1997) has some similarities with the interpretations of domestic scientists. He determines controlling as "the concept of an integrated enterprise planning and control system" (p. 37).

The methods used for this research paper are analysis, synthesis, comparison, classification and grouping of functions and objectives of studying object.

Study Area. Despite the long history of studying and development, controlling is still known as "a new way of thinking" for managers, aimed at the efficient use of resources and the sustainability of the company in the long term (Romashova, Averkin, 2014, 117). The central role in the organization of controlling process in the company is played by financial controlling. The transformation of financial controlling concept since $1990 \mathrm{~s}$ can be traced by comparison of scientific interpretations of different time periods (Table 1). 
Table 1. Different interpretations of the financial controlling concept

\begin{tabular}{|c|c|c|}
\hline Year & Authors & Definitions \\
\hline 1998 & $\begin{array}{l}\text { A. M., Karminsky } \\
\text { N. I., Olenev } \\
\text { A. G., Primak } \\
\text { S. G.Phalko }\end{array}$ & $\begin{array}{l}\text { "The subsystem of controlling, whose main task is to maintain profitability } \\
\text { and ensure liquidity, i.e. the ability of the enterprise to fulfil its payment } \\
\text { obligations at any time" }\end{array}$ \\
\hline 1999 & Ph.'Friberg & $\begin{array}{l}\text { "A set of methods for leading the accounting policies and management } \\
\text { practices of units to the form that they are effective for this business, are } \\
\text { analysed, flexible to the future changes in business and supported by } \\
\text { software" }\end{array}$ \\
\hline 2003 & V. V. Burtzev & $\begin{array}{l}\text { "A system whose main task is to provide the enterprise with a stable } \\
\text { position and accumulate its resources for the implementation of strategic } \\
\text { plans, to avoid violations and abuses that inevitably appear when there is no } \\
\text { systematic approach to working with finances" }\end{array}$ \\
\hline 2005 & T. A. Zolot'ko & $\begin{array}{l}\text { "Automatic process of financial management in the company. Control of } \\
\text { finance relations, financial resources and their sources should be } \\
\text { implemented through financial methods, models and tools of the financial } \\
\text { management" }\end{array}$ \\
\hline 2008 & O. A. Kuzakova & $\begin{array}{l}\text { "A controlling subsystem providing financial-oriented control through the } \\
\text { use of methods and tools of financial management and provision of } \\
\text { sustained flow of internal and external information" }\end{array}$ \\
\hline 2011 & O. S. Kozhuhova & $\begin{array}{l}\text { "An integrated financial management system of the organization, which } \\
\text { includes a control device that allows financial management based on the } \\
\text { standardization of financial management decisions" }\end{array}$ \\
\hline 2013 & M. Sh. Oganyan & $\begin{array}{l}\text { "It is an internal business process aimed at achieving the ultimate goals of } \\
\text { the company, including analysis, information support, planning and } \\
\text { monitoring, and changing the management methodology and company } \\
\text { behaviour (if necessary) and taking into account the psychological aspects } \\
\text { of management" }\end{array}$ \\
\hline
\end{tabular}

The table demonstrates the process of the formation of financial controlling from the subsystem responsible for the liquidity and solvency to the integration system of financial management, including analysis, information support and planning. In the broadest sense, financial controlling is understood as "a controlling system that ensures the concentration of control actions in the most priority areas of a company's financial activities, the timely identification of deviations actual results from planning ones and the adoption of operational management decisions that ensure its normalization" (Blank, 1999, p. 91).

Financial controlling is a part of the system of company's internal environment management. Its organization is based on the functions, tasks and content of financial management, depends on the features of the business activity. Initially, financial controlling was used primarily in industrial enterprises with complex production processes. Today, financial controlling is an effective tool for representatives of any industry, including tourism. 
Tourist and recreational company do not principally differ from other forms of economic activity by its characteristics and goals. As any kind of business, a tourism enterprise seeks for a stable position in the market, optimizing costs, increasing growth rates and maximizing profits. Dynamic growth of modern tourism industry causes the introduction of new methods of management and competition that will allow adapting to changes in the external environment and successfully interacting with consumers in the future. According to the definition of N. I. Kabushkin and G. A. Bondarenko (2000) tourist-and-recreational enterprise is "an organization providing a set of services for people outside the home, the most important of which are accommodation, treatment, recreation, nutrition and other recreational services, i. e. services for providing recreational and tourist products" (Kabushkin, Bondarenko, 2000, p. 13). One of the main tasks of managing enterprises of the tourist and recreational complex is to increase their competitiveness as one of the main criteria of the effectiveness of management and the provision of services.

The role of financial controlling in the management system of a tourist-recreational enterprise can be assessed by considering its functions and objectives which can be reached by it (Table 2).

Table 2. Functions and objectives of financial controlling at the recreational enterprise

\begin{tabular}{|c|c|}
\hline Function & Objectives \\
\hline Financial strategy & $\begin{array}{c}\text { Development of financial strategy; } \\
\text { Adaptation of the organizational structure to the market } \\
\text { situation; } \\
\text { Diversification of activities and funding sources }\end{array}$ \\
\hline Planning and Budgeting & $\begin{array}{c}\text { Development and optimization of the internal methodology of } \\
\text { forecasting and budgeting; } \\
\text { Support of budgeting process; }\end{array}$ \\
& $\begin{array}{c}\text { Mevelopment of investment and other budgets } \\
\text { Report preparation; }\end{array}$ \\
\hline Budgetary control & Analysis of deviations of economic indicators; \\
& Analysis and control of financial activities; \\
& Identification of budget opportunities \\
\hline Internal consulting & Providing recommendations to management \\
\hline Information support & Analysis of economic situations, new trends of tourist market; \\
& Continuous information flow \\
\hline
\end{tabular}

Financial controlling is able to ensure: economic stability of the company, organization of effective financial management, creation of sustainable prerequisites for economic growth and guaranteed profitability. Effective financial management system of a tourist company can be built only with tight planning of all financial flows, processes and relations of the firm. Planning is connected, on the one hand, with the prevention of wrong actions in the financial field, on the other hand - with a reduction of the number of unused opportunities. An effective financial controlling system for a tourist-recreational enterprise is presented in Figure 1. 


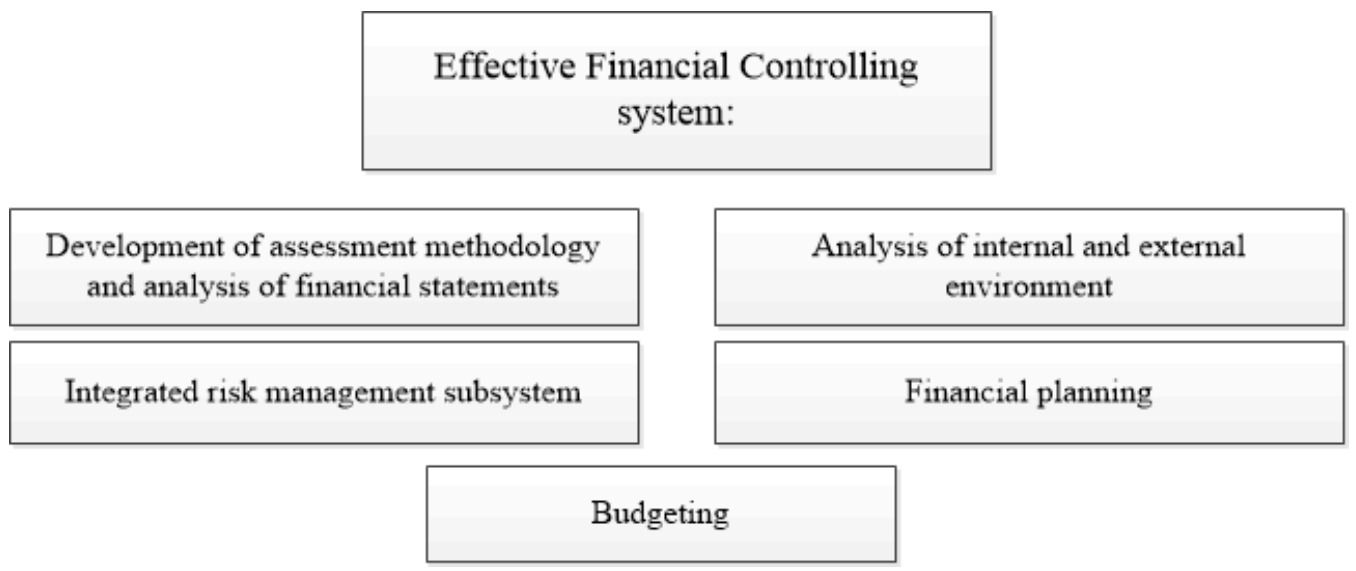

Figure 1. Structure of effective Financial Controlling system

Planning is connected, on the one hand, with the prevention of wrong actions in the financial field, on the other hand - with a reduction of the number of unused opportunities. An effective financial controlling system for a tourist-recreational enterprise is presented in Figure 1.

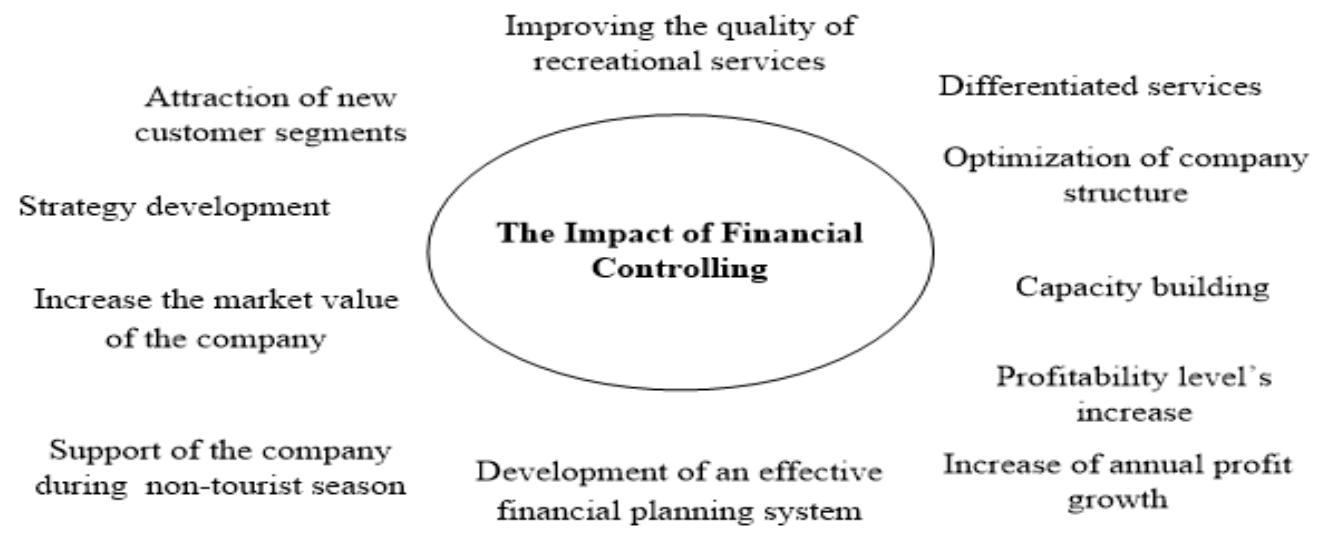

Figure 2. The impact of Financial Controlling system on activity of recreational company

The system of financial controlling to some degree is the guarantor of the successful operation of the enterprise in the long term. Financial controlling allows a tourist-recreational company to achieve certain goals (Figure 2).

\section{RESEARCH RESULTS AND DISCUSSION}

Controlling as a modern concept of business management takes on an increasingly important role in the tourist and recreational sphere, this is due to a number of factors:

- The instability of conditions and characteristics of the external environment: the growing influence of the political factors and external economic situation on the development of the industry;

- Development of new kinds of tourism, changes in the structure of tourist market;

- Increasing amount of information and growth of the importance of the fast tactical and strategic management decisions;

- Complication of management systems, expansion of sales channels; 
- Internationalization of market relations and entrepreneurial activities.

In recent years, many factors of external instability have influenced the Russian enterprises of the tourist and recreation market, they are:

- The collapse of the rouble towards the US dollar and the Euro on December 16, 2014: the purchasing power of Russians declined;

- Bankruptcy of large operators and airlines;

- The withdrawal of Egypt and Turkey from the market in 2015: October 6 - the suspension of air communication with Egypt, since November 28 - the ban on the implementation of charter flights between Russia and Turkey;

- Political and economic sanctions: reorientation of tourist flow, development of domestic tourism.

These events could hardly be foreseen, however, with the help of financial controlling and a crisis management program, businesses were able to withstand in a difficult economic situation. The closure of international tourist destinations has resulted in the growth of domestic tourism. Enterprises that managed to assess the situation in short time and draw up a new strategy of action even benefited from the current situation. In the modern post-industrial society, the role of information as a factor of production and driving force is extremely high. Financial controlling is a tool that helps to accumulate information resources for making correct and timely management decisions. One of its key tasks is the detection of crisis phenomena and the development of countermeasures.

\section{CONCLUSIONS}

1. The main task of financial controlling is to maintain profitability and ensure liquidity, i.e. the ability of the enterprise to fulfil its payment obligations at any time that is most relevant for the tourism industry. Among the key challenges faced by resort companies, it is important to headline the seasonality of demand, which largely affects the using of their material resources. The duration of the active period can vary from 90 to 180 days; it often depends on climate and a number of other factors (Zlenko, 2015). In order to stabilize the work during the off-season, maintain financial stability and solvency in recent years many tourism and recreational enterprises began to strive for the introduction of modern management systems.

2. An effective system of financial controlling at a tourism and recreational enterprise allows fully assessing the current position of the company, making forecasts and successfully resisting external destabilizing factors.

\section{REFERENCES}

1. Bekeris, R. (2012). The impact of macroeconomic indicators upon SME's profitability. Ekonomika, 91 (3), p. 117-128.

2. Blank, I. A. (1999). Fundamentals of financial management. T.1. Kiev: NikaCentre: Elga.

3. Bughin, J., Manyika, J., Woetzel, J. (2016). The age of analytics: Competing in a data-driven world. McKinsey Global Institute. Internet link: www.mckinsey.com/mgi. MGI-The-Age-of-Analytics-Fullreport.pdf 
4. Burtzev, V. V. (2003). Finance controlling: Options and directions. Management today, 5, 12-15.

5. Danilochkina, N. G. (1998). Controlling as an Instrument of Business Management. Масква.: Audit. Unity.

6. Deyhle, А. (2001). Controller - Praxis. Management Service. Москва: Finances and statistics.

7. Freiberg, F. (1999). Financial Controlling. The concept of financial stability of the firm. Financial Newspaper, 13, 15.

8. Hahn, D. (1997). Planning and Control: Conception of Controlling. Translation from German. Москва: Finances and statistics.

9. Kabushkin, N. I., Bondarenko, G. A. (2000). Management of Hotels and Restaurants. Moscow: New Knowledge, Ltd.

10. Karminsky, A. M., Olenev N. I., Primak, A. G., Phalko, S. G. (2002). Methodological and Practical Principles of Controlling in Organizations. 2 edition. Москва.: Finance and Statistics.

11. Kazansky, D. (1999). Financial controlling: Point of view. Financial newspaper, 36.

12. Kuzakova, O. A. (2008). Formation of the Mechanism of Financial Controlling at the Enterprises of the Russian Federation: dis. Econ. Sciences. SPb.

13. Mann R., Maier A. (2004). Controlling for Newcomer. Translation from German. Москва: Finances and statistics.

14. Oganyan, M. Sh. (2013). Nature of financial controlling at entity Vestnik of Omsk University. Series Economics, 1, 148-151.

15. Romashova, I. B., Averkin, M. G. (2014). Controlling as a Modern Concept of Financial Management. Materials of the IV International Scientific and Practical Conference (pp. 117-125).

16. Sulina, E. I. (2016). Formation of a system model of enterprise management of the tourist and recreational sphere. Taurian Scientific Observer, 5-1 (10), 149-155.

17. Utkin A.A., Myrynjuk E.V. (1999) Controlling: Russian practice / A.A. Utkin,- M.: Finances and statistics. $272 \mathrm{p}$

18. Vostroknutova, A. I., Romanovsky, M. V. (2014). Corporate Finance: A Textbook for Universities. St. Petersburg.

19. Zlenko, D. G. (2015). Management changes at the enterprises tourist areas. The scientific Vestnik, 4, 4447.

20. Zolotko, T. A. (2005). Financial Controlling and Monitoring of Corporate Cash Flows: Auto ref. Dis. Can. Econ. Sciences. Volgograd.

\section{THE ROLE OF FINANCIAL CONTROLLING IN THE MANAGEMENT SYSTEM OF TOURISM AND RECREATIONAL COMPANY}

\section{Maia Seliverstova}

Sochi State University, Sochi, Russia

\section{ABSTRACT}

In the modern world tourism and recreation are highly profitable activities, which also have a significant impact on the economy of the country, contributing to the inflow of foreign currency, creating new jobs, improving infrastructure and so on. In the conditions of economic instability and high level of market competition, success of financial-economic activity of tourist enterprises is determined by the efficiency of 
decision-making that directly depends on the total access to information about the financial state and existing risks.

The aim of the research was to identify the role of financial controlling in the management system of tourist-and-recreational company.

Research methods used for this research paper were analysis, synthesis, comparison, classification and grouping of functions and objectives of the object being studied.

The object was the role of financial controlling in the management system.

It is believed that controlling as economic term was discovered in Europe in the 15th century, after that it gained a wide development in the United States. In Russia, the concept of controlling became popular in the 1990s.

Conclusions: 1. The main task of financial controlling is to maintain profitability and ensure liquidity, i.e. the ability of the enterprise to fulfil its payment obligations at any time that is most relevant for the tourism industry. Among the key challenges faced by resort companies, it is important to headline the seasonality of demand, which largely affects the using of their material resources. The duration of the active period can vary from 90 to 180 days; it often depends on climate and a number of other factors (Zlenko, 2015). In order to stabilize the work during the off-season, maintain financial stability and solvency in recent years many tourism and recreational enterprises began to strive for the introduction of modern management systems. 2. An effective system of financial controlling at a tourist and recreational enterprise allows fully assessing the current position of the company, making forecasts and successfully resisting external destabilizing factors.

Keywords: financial controlling, control system, tourism and recreational company. 